\title{
OPTIMIZING CITY DIPLOMACY INDONESIA FOR ECONOMIC DEVELOPMENT THROUGH E-GOVERNMENT IMPLEMENTATION
}

\author{
Sylvia Octa Putri \\ Department of International Relations, Universitas Komputer Indonesia, Bandung, \\ Indonesia
}

\begin{abstract}
This research wants to identify the implementation of e-government conducted by the city government in Indonesia that could synergize and support city diplomacy activity in boosting city economic development. The research method was qualitative methods, with data collection techniques through literature studies. The results showed that the implementation of Egovernment in several cities in Indonesia are still focused on improving the quality of public services, using the use of information technology through the pattern of Government to Citizen (G2C), Government to Business (G2B), Government to Government (G2G). The orientation of data and information distribution is still focused on the local population. The use of multilingual or foreign language options in accessing information is still less optimal. Various fields that can boost the city's development, such as investment, trade, and tourism with a focus on overseas audiences, are informed well but the data or information presented is not integrated into one portal. Some cities that are doing sister cities cooperation also do not provide information about their sister city's partner. There are several cities that are considered doing city diplomacy very well, by combining the e-government implementation and city diplomacy will greatly improve and accelerate the city's economic development, and the city could be becoming an important player at the global level.
\end{abstract}

Keywords: City Diplomacy, E-Government, Economic Development

DOI: http://dx.doi.org/10.15549/jeecar.v9i1.884

\section{INTRODUCTION}

The Study of International Relations looks at the increasing role of sub-national governments in international relations. The involvement of local governments in international relations is called Paradiplomacy. In the era of globalization, this phenomenon is so strong along with the open access and increased role and influence of non- state actors in the arena of international relations. The region can promote trade, investment, and various potential cooperation that cross the borders of state jurisdiction. Paradiplomacy is the development of direct foreign relations conducted by subnational actors, who have certain objectives in various fields aimed at the welfare of the subnational government under the supervision of the 
National Government to face globalization (Kuznetsov A.S, 2015).

The strongest motivation behind the emergence of the regional government's desire to conduct diplomacy activities is economic factors. The purpose of the region to conduct Paradiplomacy, in this case, is to attract foreign investment, attract multinational companies to its territory, and target new export markets, develop tourism and other fields that can improve the region. Its function is solely to compete at the global level, so it has no political factors at all. One form of paradiplomacy is Sister City. Sister cities or twin cities are partnership relationships that are established in the context of inter-city relations in mutually beneficial and mutually assisting cooperation and adhere to the principle of equal treatment. In the cooperation of the sister, the regional government has conducted diplomatic activities that have specific objectives in various fields aimed at the welfare of the subnational government under the supervision of the national government (Michaelmann, H \& Soldatos, P, 1990).

City diplomacy could be considered a form of decentralization of international relations management, choosing cities as the key actors. The representatives of cities involved in city diplomacy will be mayors, given that they are often responsible for the international relations of their city ( Rogier Van der Pluijm \& Jan Melissen, 2007).

The development of Information and Communication Technology is a new opportunity for the Government by utilizing it in government implementation to achieve efficiency, effectiveness, transparency, and accountability in government performance, which then leads to the realization of improvements in government services to the community. Government administration using Information and Communication Technology is known as Electronic Government or E-Government. The Ministry of Information and Communication of Indonesia defines e-government as the application of internet-based information technology and other digital devices managed by the government for the purposes of conveying information from the government to the public, business partners, employees, business entities, and other institutions online, where egovernment can be interpreted as the process of utilizing information technology as a tool to help run the government system more efficiently. Central government agencies and autonomous regional governments implement e-government by developing public services through communication and information networks in the form of websites.

The study of paradiplomacy and e-government activities has been conducted by the author in previous research; however, this study still focused on e-government implementation in Bandung, Indonesia (Adibowo, R. \& Putri, S.O. 2016). Another study was also conducted by Edwi Arief Sosisawan in evaluating the implementation of e-government in Indonesia. In his paper, Edwi discussed that the management of local government websites in Indonesia is still in the form of a company profile or limited to web presence only. Application services needed as a means of e-government such as KTP creation services, e-employment, legal services, and so on seem to be far away and this is a challenge for all local governments to improve their e-government status (Sosiawan, E.A). Another study was conducted by Adirini Pujayanti entitled where she pointed out that Paradiplomacy with the involvement of local governments as part of Indonesia's multitrack diplomacy is a real demand in international relations in the era of globalization (Pujayanti, A. 2016). In other research, Jose M.Magone developed the concept of typology of paradiplomacy, which is a type of transnational paradiplomacy, where the state is the "gatekeeper" in paradiplomacy, while "the real actor" is a local/local government and community group (Magone, J.M) Adam Grydehoj also wrote in his paper that paradiplomacy can achieve policy goals when he succeeds in slipping under the political radar of a sovereign state (Adam Grydehoj), Some of the previous studies above have provided a comprehensive overview to the author about the concepts of paradiplomacy, that could be said as city diplomacy (because are doing by the subnational government) and implementations of egovernment. Some studies describe that city diplomacy is incoherent with Paradiplomacy, given that state and city actors do not necessarily "ride" along different diplomatic routes, but rather along the same route although in a different car. In this case the authors see the relevance of city diplomacy and paradiplomacy is still very coherent in this study considering the implementation of city diplomacy in Indonesia 
still refers to one door policy in terms of foreign policy, in this case we can see Nations talks, Cities Act. However, there are still very few studies that researched the linkage of city diplomacy and the implementation of e-government in local/city governments. In fact, in the digital era and transformation, cities all over the world implement e-government to improve the quality of public services and distribute data and information to various parties. By doing city diplomacy in e-government will improve city government performance. The phenomenon of city diplomacy and e-government activities is encouraging the curiosity of the author to see how city diplomacy activities carried out by the city government can work together with egovernment implementation.

This research wants to identify the implementation of e-government conducted by the city government in Indonesia that could synergize and support city diplomacy activity in boosting city economic development. The authors in this context provide an overview of how city diplomacy and e-government implementation activities could synergize, as we can take a lesson learned from Seoul Metropolitan City, the capital of South Korea. From the author's point of view, Seoul Metropolitan City has succeeded in combining e-government implementation and city diplomacy. The Republic of Korea got the best 5 E-Government ranking in the world from 20102020 based on United Nations E-Government Development Index (UN-EGDI) report. The best implementation of E-Government is certainly applied systemically and structured across government institutions in South Korea, including in local or municipal governments. To support the validity of the data, this study used qualitative research methods by collecting data through literature studies. The novelty of this study is the linkage between the implementation of egovernment and city diplomacy could synergize and support each other and gives benefit for city development, so the strategy in combining these two activities should arrange well by the city government in Indonesia, here author gave a recommendation in e-government and city diplomacy strategy concept to develop further by the city government in Indonesia.

\section{LITERATURE REVIEW}

Diplomacy can be defined as institution and processes by which states and other represent themselves and their interests to one another (Melissen \& Sharp, 2006). Given that engaging in relationships and pursuing national interests are crucial elements of diplomacy, any definition of city diplomacy should include these elements as well. City diplomacy could be defined as the institutions and processes by which cities engage in relations with actors on an international political stage with the aim of representing themselves and their interests to one another. City diplomacy with such a definition could be considered a form of decentralization of international relations management by choosing cities as the key actors.

The city becomes a key actor in diplomacy can be seen from two logics, First, the logic of efficiency and effectiveness: a good city governance is seen - especially by some mayors animated by personal determination - as the best instrument to achieve social effectiveness because of its directness and proximity to citizens. Second, In the logic of democracy, instead, a good city governance is seen as the best tool to implement the democratic ideal (localities become instruments for achieving community empowerment and democratic selfdetermination. As a matter of fact, city diplomacy can originate also from bottom-up pressure of citizens' activism (Marchetti, 2021)

E-Government is the use of ICT to promote more efficient and effective government, facilitate more accessible government services, allow greater public access to information, and make government more accountable to citizens. E-government is about transforming government to be more citizen-centered. Technology is a tool in this effort (Pacific Council On International Policy Document, 2002)

E-Government in diplomacy has gained its momentum with regard to not only managerial efficiency but communication potential. By Egovernment implementation, governments can take advantage of interactive interfaces on the web for diplomacy purposes (Hyung Ming Lee, 2013)

Based on two logics conveyed by Marchetti and the role of E-Government that transforms government to be more citizen centered and also communication potential in e-government implementation, therefor becomes a meeting point between city diplomacy and egovernment. E-Government as technology (Internet) has played an important role as a 
virtual space for communication, interaction between government and society. When we viewed from the development of cyber space as a new arena in interaction between international relations actors, then the cyberspace is now a venue for competition among international actors as well as an arena for conflicts, contentions and also diplomacy. E-government can be a venue of diplomacy.

\section{METHODOLOGY}

This paper's used qualitative research methods by collecting data through literature studies. Literature study explores various information in books, scientific journals, newspapers, magazines, and sources of information from articles and news through websites/websites on the internet. Some cities government official's websites in Indonesia were being observed by the author and compared to Seoul Metropolitan City official's websites, such as menu pages, articles and news posts, website performance, and information.

Some features like multiple language options in the website are observed by Author. Other features like cities' profile and cities' potential resources like trade, tourism, and investment are searched by the author just by clicking on the menu/page or using searching options on the website. The author also sees the menu/page about sister city on the city government website. The reason why the author searched this menu/page is that the sister city indicates how the city government engages itself in international relations / global stage level and optimizes their role as an actor of diplomacy. For the G2G, G2C, and G2B pattern in e-government service, the Author compared this service as provided by the city government in Indonesia and service that was provided by Seoul Metropolitan Government. This method is useful to identify who is the target audience of this service.

\section{RESULTS}

The implementation of E-Government in Indonesia has been started in 2001, and in its development has been the benefits of government institutions and the public, especially related to public services and good governance. City governments have implemented e-government focusing on Government to Citizen (G2C),
Government to Business (G2B), Government to Government (G2G).

Based on the Local Government Website Management Guide issued by the Indonesian Ministry of Communication and Information. The Development phase of local government websites starts from the Web Presence stage, where local government websites convey information that is the obligation of public institution to be able to convey it to the public. On this stage what happens is a one-way communication, where the government publishes various data and information that it has to be directly and freely accessed by the public and other interested parties through the internet. For example, the public can access and download regulations and laws, the public can access the results while elections, students or researchers can access statistical data that can be used as secondary data. The second stage is Interaction, on this stage there is two-way communication between the government and the concerned community. People can have discussions directly (chat, teleconference, web-TV, etc.) or indirectly (through e-mail, frequent ask questions, newsletters, mailing lists, etc.).

The next stage is Transaction, there has been access to demand and provision of data / information and financial transactions. At this stage the available applications are more complicated because they must have a security system and protection against the transacting parties. For example, such as applications that allow the Community to take care of applications for the creation of administrative documentation such as ID Card, Birth Certificate, Passport. Other applications such as tax report, projects procurement such as e-procurement whose business processes are conducted online, or farmers can sell their crops to government logistics agencies or exchange buying and selling. The last stage is Transformation / Integration, at this stage the website has been managed seriously and integrated with the back office information system.

Based on content, the minimum contents on the website in local government are:

a. Briefly Profile explaining the existence of the agency concerned (history, motto, region, emblem and meaning of emblem, location in the form of maps, visions and missions). 
b. Agency profiles, organizational structure, name, address, telephone, e-mail from local officials. Basic tasks and functions

c. Human Resources Profile, it is necessary to display the officials in the agency.

d. Program Budget Summary, Explaining about the program budget summary / agency activities / local government agencies

e. Regulations / Policies Explain regulations / policies that have been issued by agencies that need to be known by the public so that they can be socialized to the wider community.

f. News from the local government agency, not taken from local newspapers. It is expected that the news website becomes a reference or reference for news published by local newspapers.

g. Documentation of Activities, conveying to the public documentation of the implementation of activities that have been carried out by agencies in the form of narratives accompanied by photo / video documentation

In addition to the six minimum contents mentioned above, government websites must also be able to interact with the public through twoway communication between website managers and visitors through:

1. Chat/Forum/Discussion, is a feature on a website that can be used by registered users to exchange information between users or with the website manager. Discussion forums can be grouped in several forums according to the topic of chat / discussion.

2. Suggestions/Comments / Guest Books, It is a feature on the website that can be used by the user (not necessarily registered) to convey the enter to the website manager. This feature can also be an early stage of a form of community complaint through the website.

The author visited several city government websites in Indonesia such as Jakarta, Bandung, Medan, Surabaya, Yogyakarta, Bogor, Bali and several other cities in Indonesia. In terms of website content, a number of city government websites in Indonesia have qualified website content as recommended by the Government of Indonesia through the Ministry of Communication and Information.
Similarly, in the pattern of interaction that occurs with the implementation of egovernment, namely Government to Citizen (G2C), Government to Business (G2B), Government to Government (G2G) has been going well. For example, in G2G pattern, local governments websites in Indonesia are connected/linked to various institutions and other government agencies both municipal and central government agencies. In G2B, the city government has connected, interacted and transaction to business people, companies that follow online procurement, small medium enterprises business and G2C actors through two-way interaction with the community/people through email, guest books, report features, and so on.

With regard to diplomacy practice in the implementation of e-government, the authors found that the implementation of E-government in several cities or regencies in Indonesia are still focused on improving the quality of public services, using the use of information technology through the pattern of Government to Citizen (G2C), Government to Business (G2B), Government to Government (G2G). It's very good, but in this matter is not globally oriented. The orientation of data and information distribution is still focused on the local people. This phenomenon can be seen from the lack of multiple language options on the city government's website. Research conducted by the Author on various local government websites in major cities such as Jakarta, Bandung, Medan, Surabaya, Yogyakarta, Bogor, Bali and several other cities in Indonesia are still fewer who use multiple language option features. If there are multiple language options but it does not work well. In this case, the author saw that the orientation of the City Government is still only for local residents/audience, not yet targeting the global reader/audience. So that multilingual options on websites are very important because it could be a gateway for the international audience to get to know about cities in Indonesia, this can be seen in a figure below as implemented by Jakarta government in providing multiple language options. (https://jakarta/go.id) (see Fig. $1)$. 


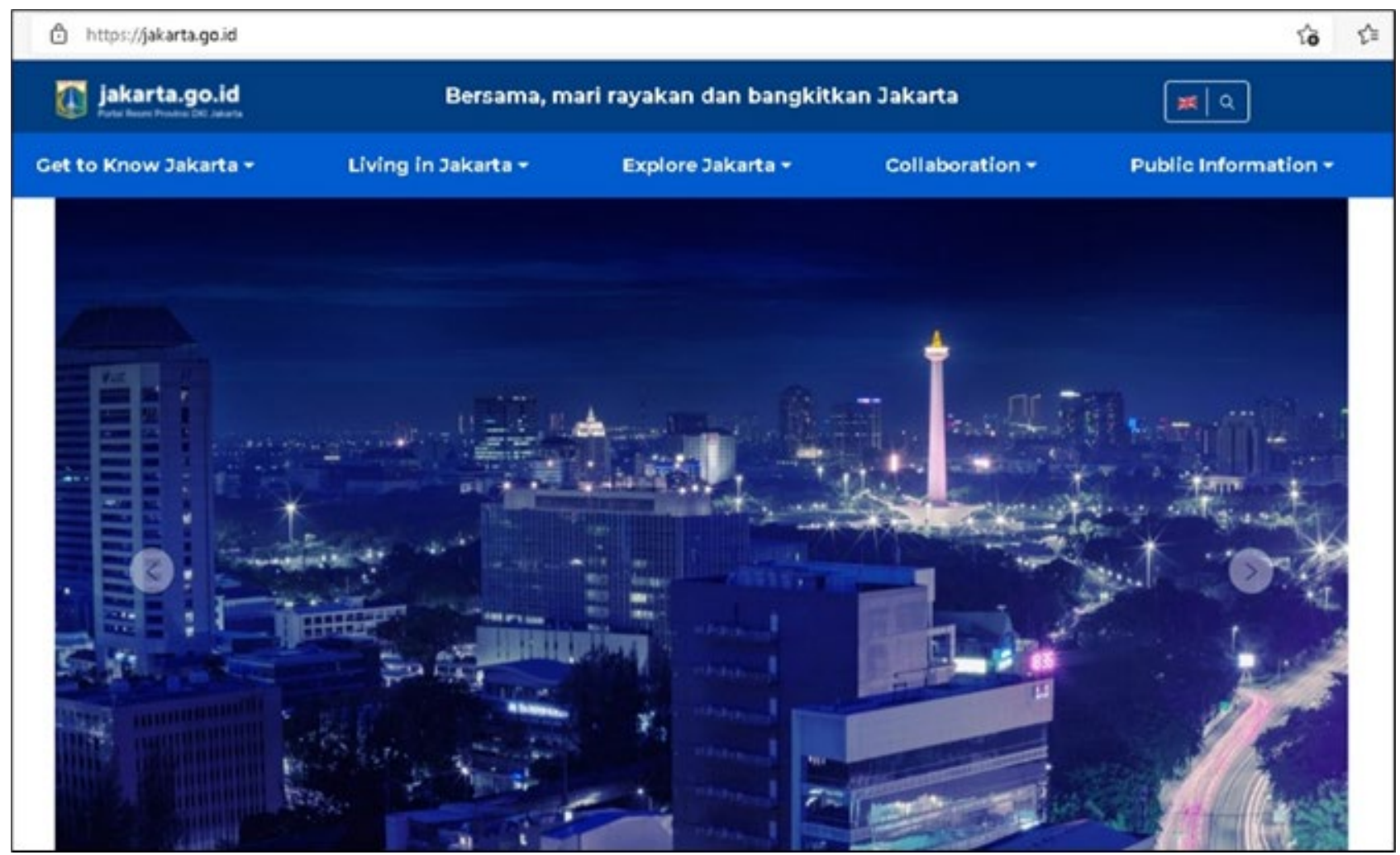

Figure 1: Multilanguage Options in Jakarta Government Website Source: Official Website of the Jakarta City, https://jakarta.go.id

Other findings that related to paradiplomacy, the author found that many cities in Indonesia have sister city cooperation with cities in other countries but the information about sister city cooperation with partners around the world is not provided yet, in this case it has not been integrated or not presented in a special page (on website) about sister city cooperation. However, information about the sister city can only be accessed through daily news posts, not available on pages or special menus. There was information about sister cities, but the information can be accessed through the cooperation division or other divisions of the city government, not integrated into the same portal.

Related to the economic development of the city, the various potentials of the city in various fields have been well informed and promoted by the city government through its website. But in the context of diplomacy, unfortunately, there is still less information to be accessed by the global community because of language constraints. Due to this language limitations, global readers/ audiences will find it difficult to capture the information and potential that the city has. In this matter The information that provided possibly to opportunities for cooperation that could be benefit and contribute to the development of the city. In cities government websites, we can explore through the regional potential menu seen on almost all local government sites such as investment information, tourism, local smallmedium enterprises (SME), and trade. Still in diplomacy context, there are interesting findings in the website of city government is the features for tourist attraction (tourism sector) there are such as local culture displayed on city government sites such as folklore menu, local caricature, local language on cities government websites (such as Medan City, Sumatera) (https://pemkomedan/ go.id) (See Fig. 2). 


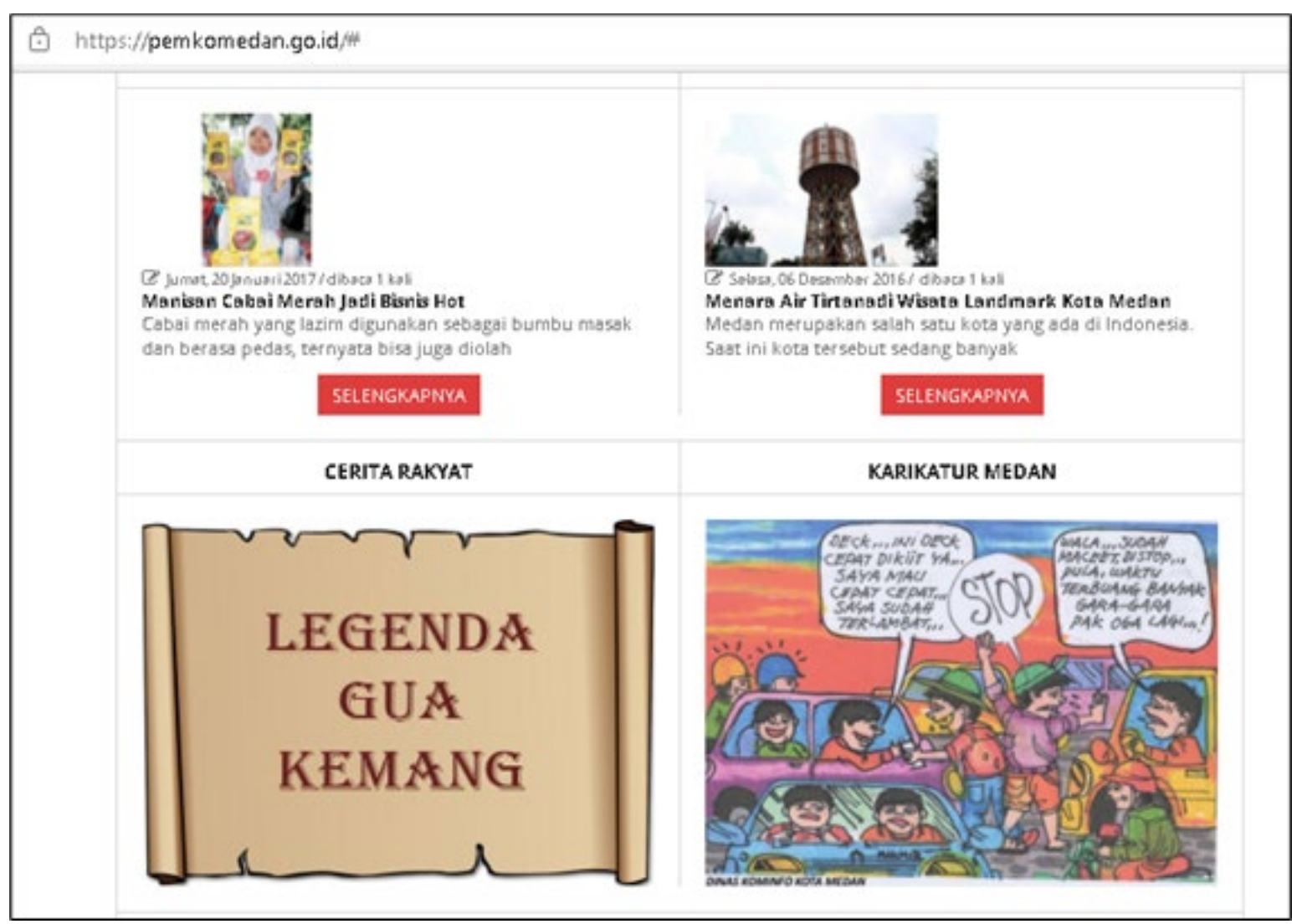

Figure 2: Folklore in Medan E-Government

Source: Official Website of the Medan City, https://pemkomedan.go.id

Lesson Learned from Seoul Metropolitan City: "E-Government featuring City Diplomacy"

In a report issued by UNEGDI, South Korea since the period 2010-2020 was included in the top five of UNEGDI rankings, where South Korea became one of the countries with the best E-Government implementation in the world. The author assumes that the best implementation of E-Government is certainly applied systemically and structured across government institutions in South Korea, not least in local or municipal governments. The author browsed the Seoul Metropolitan City government website through english.seoul.go.kr. On the initial page of the Seoul City government, we can see the profile of Seoul City, which is presented with great interest. "I Seoul You " is a Seoul City brand that has the meaning of representing Seoul as a place for people from across the globe to connect and feel like they belong. Between "You" and "I," among citizens and people all around the world, Seoul is at the center of all relationships (English.seoul.go.kr).

There are several page options such as About Seoul, City Hall, Policy, Service, and News, where each page displays various information and public services provided by the Seoul City Government, such as Smart Complaint, where Seoul residents can file a complaint through Smartphone Apps. Mobile Democracy where Seoul Residents can vote on Public Policy decisions through the app, Oasis of 10 Imagination (brilliant ideas came from Seoul residents that would be realized by the Seoul City Government), Seoul CCTV Integrated Call Center, High-Speed Information Communication Network, which connect 36 Seoul District (see Figure 3).

Related to diplomacy activities, we can see on the International Exchange page. There is various information such as International Relations News, which displays various international news that the City of Seoul is involved in. Then also, on this site, we can also see a special page about Sister and Friendship Cities from Seoul around the world. Not to be left behind, all sister cities and friendship partners of Seoul city information is also displayed on this page. 


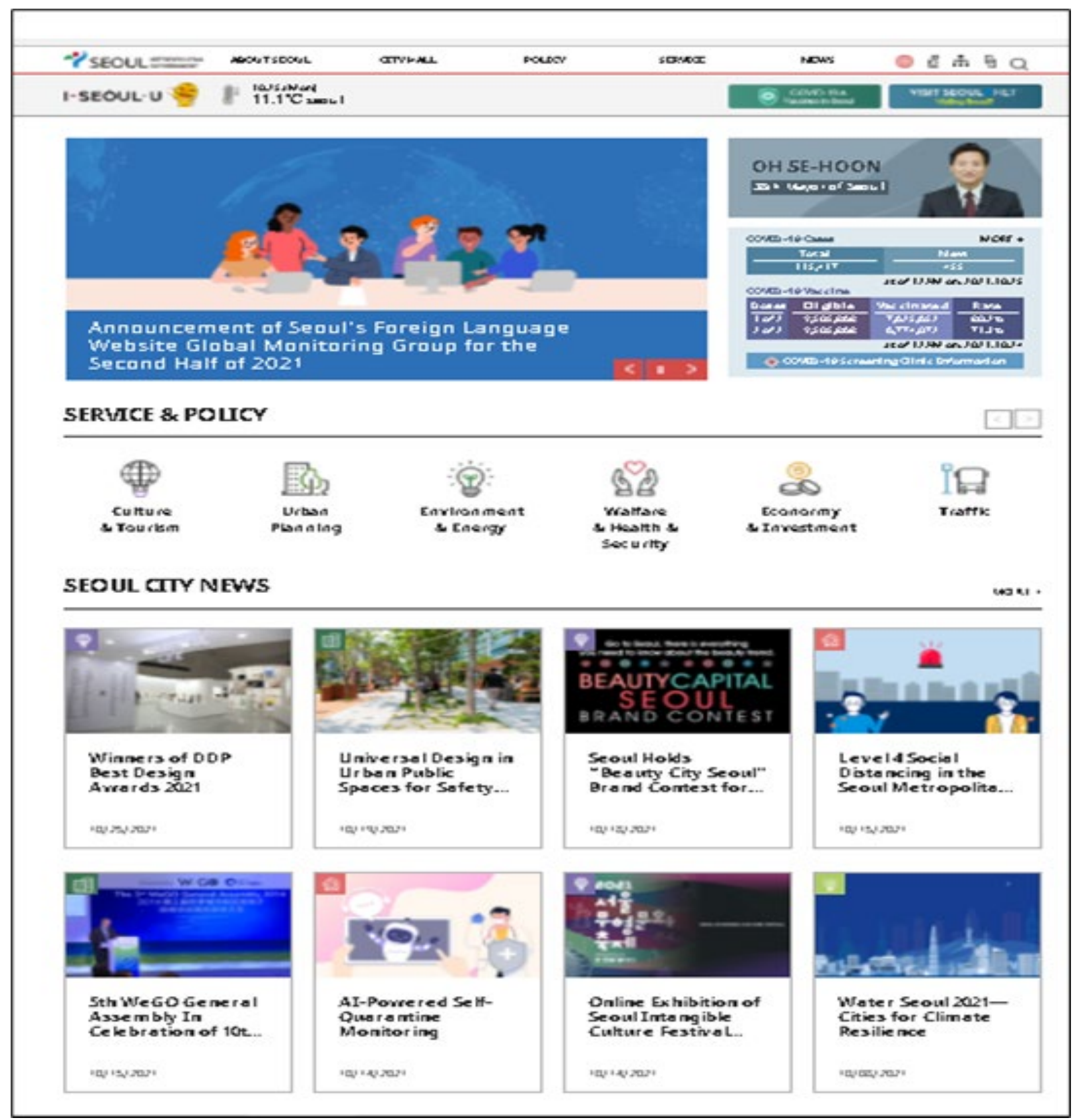

Figure 3: Seoul Metropolitan E-Government

Source: Official Website of the Seoul Metropolitan Government, english.seoul.go.kr

There is also information about the International Organization, where the Seoul Metropolitan Government will provide information on international organizations of which it is a member upon request. Interestingly, Seoul City also has a special page on Honorary Citizens; namely, The Seoul Metropolitan Government bestows honorary citizenship to foreigners who love Seoul and contribute to the development of Seoul's municipal administration. Honorary citizens are conferred with a certificate of distinction, encouraging them to keep making efforts for the advancement of Seoul as a global city. The city of Seoul also has other interesting information such as Support for Multicultural Families, which is aimed at strengthening the capabilities of marriage immigrants, supporting the education of children of multicultural families, reinforcing healthy multicultural family relations, and fostering a sound multicultural society. 


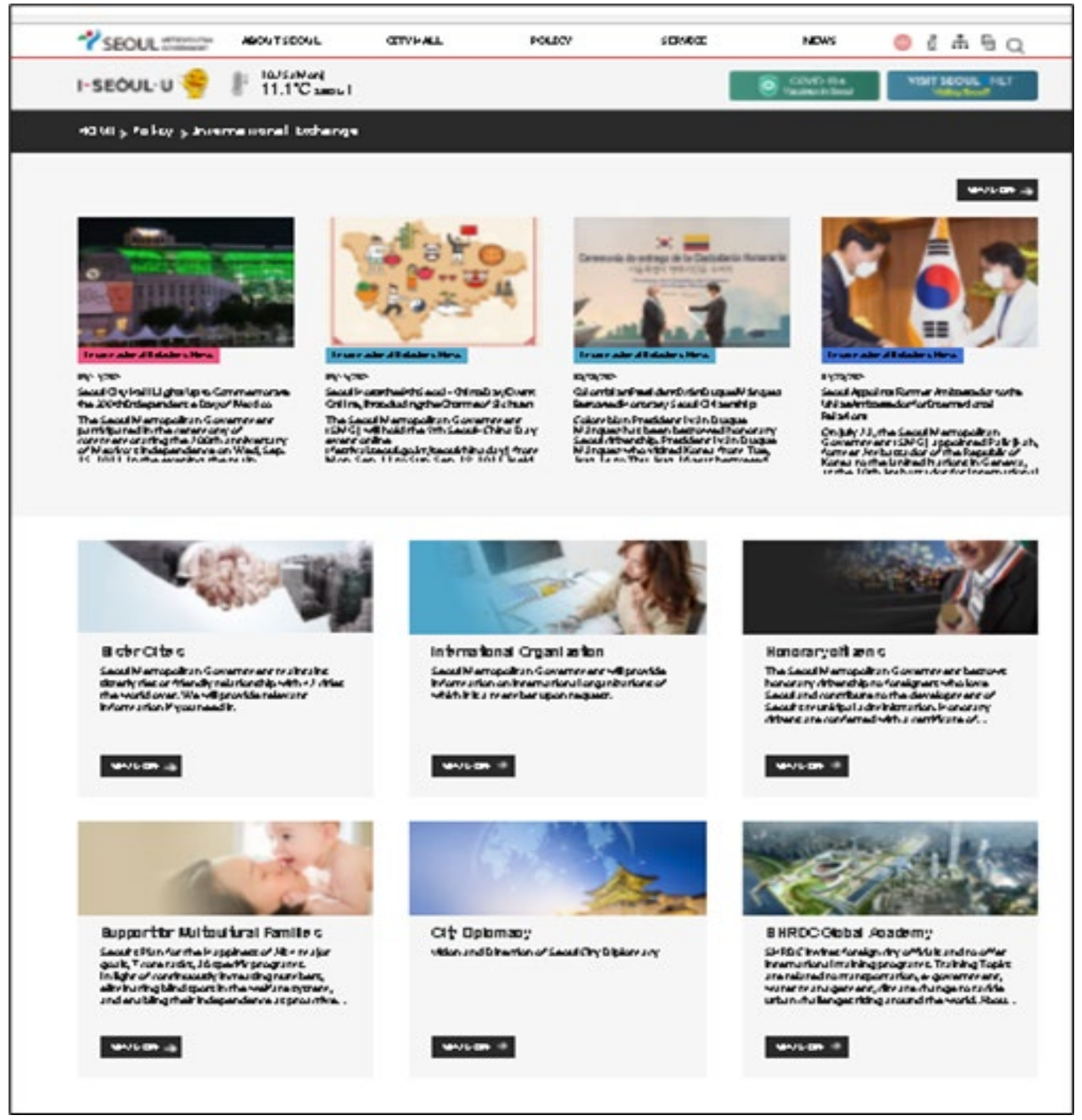

Figure 4: Seoul City Diplomacy

Source: Official Website of the Seoul Metropolitan Government, english.seoul.go.kr

The city of Seoul also features its city diplomacy strategy through the vision \& direction of Seoul City Diplomacy so that it has a clear target as a global city. The city of Seoul also has a Seoul Human Resource Development Center (SHRDC) of Seoul Metropolitan Government that has been contributing to solving global urban issues by sharing Seoul's policies for the urban issues through international training programs. The SHRDC invites foreign city officials to 5-10-day international programs, including lectures, policy presentations by foreign cities, site visits, and interactive discussions (see Fig. 4).

In addition, there is also a lot of information for foreign tourists who want to visit Seoul City, such as entry visas, access to Seoul city with various modes of transportation that can be accessed from Incheon Airport, and currency exchange. This is very helpful for foreign tourists who want to visit Seoul City. In the event and announcement menu, Seoul City also attracts the global community to love Seoul City through photo contests, and participants will get interesting prizes. The multiple 
language option features in English, Chinese, Japanese and worldwide language make it very easy for visitors to access information about Seoul City. In this case, the author saw that the implementation of The South Korean EGovernment has been going very well throughout the government sector, not least the local government. City diplomacy conducted by the Seoul city government in the implementation of E-Government can make Seoul a city dreamed by the world community to visit.

\section{DISCUSSION AND CONCLUSION}

The author in this case tried to described that the Seoul City performance website can be adapted with the construction of the cities government websites in Indonesian where the content website can be synergized with city diplomacy activities., such as:

a. In the briefly profile about City, this profile should be accessed in multiple languages. For cities that cooperate with sister cities, they should display a multiple of languages option that can be accessed with the country language from their partner city. For example, the Bandung City Government, Indonesia have a sister city cooperation with Suwon City, Republic of Korea, so then the multiple language option is provided in Indonesian or Korean. On city's attributes such as motto must have a global vision, as done by the Seoul City Government with the Motto I SSEOUL. U' was developed as a relationship-oriented brand to embrace the diversity of communities in Seoul and represents Seoul as a place for people from across the globe to connect and feel like they belong. The geographical location of the city must be given an identity, as seen in Seoul website which is Seoul as The Gateway to Asia and Europe. This identity gives Seoul characteristics as a Global Cities as well as New York, Tokyo and London.

b. Agency profiles, organizational structure, name, address, phone, e-mail from county officials and basic tasks and functions. On this profile all institutions in the city government are also displayed and can be accessed with multi-lingual options. Profiles of agencies, such as tourism agencies, investment agencies, trade agencies must be accessible information and open opportunities for international readers/audience such as government / investors / business people / tourists to access the information they need.

c. Regarding the Human Resources Profile, regional officials should be able to act as actors of diplomacy. Seoul is designing a good strategy in city diplomacy, with the Mayor of Seoul as its actor of diplomacy. The public is also given access to twoway communication with the mayor with the existence of Dear Mayor feature in website. (See Fig. 5)

d. Work and activities program, Seoul City government websites fully informs about their program activities. One of the very brilliant phenomena of their programs that can be adapted from the Seoul City Government is the combining of egovernment and city diplomacy activities that can be found in the websites page of Sister Cities, International Organization (of which Seoul City participates as a member), Honorary Citizen, Support for Multicultural Families, City Diplomacy and SHRDC Global Academy.

e. In the content about City Program Budget Summary, the Seoul City Government displays a summary of the agency's program/activity budget in the form of a very informative pie chart. This demonstrates the transparency and accountability of the city government.

f. In the content about Regulations / Policies Explaining Regulations / Policies that have been issued by the Seoul City Government can be seen from the Policy page, all policies are informed very fully ranging from urban planning, economy \& investment, transport \& energy, culture and tourism, welfare health \& security, education, women \& children. As for city diplomacy can be seen on the International Exchange policy page, 


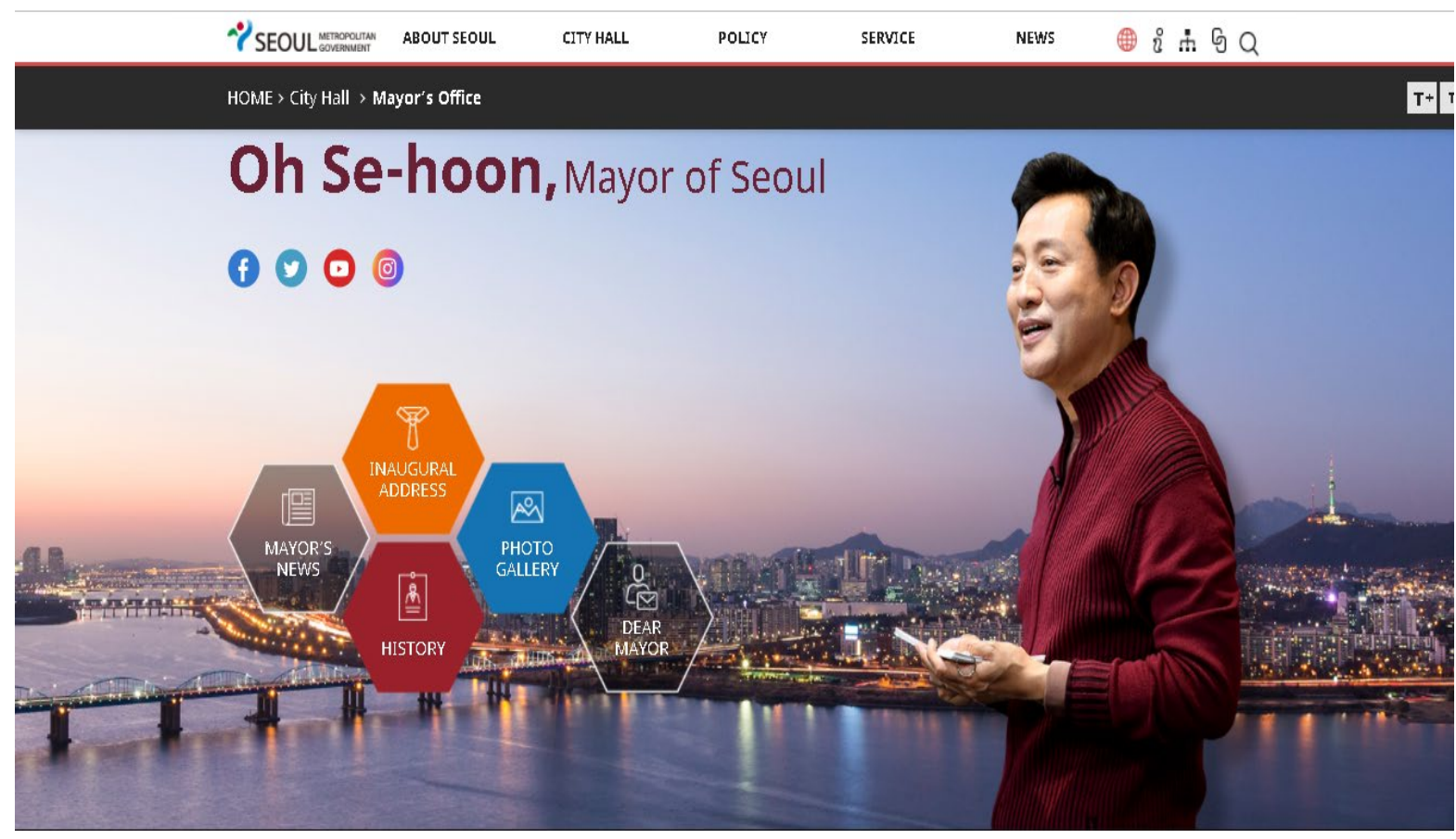

Figure 5: Mayor of Seoul as Actor of Diplomacy

Source: Official Website of the Seoul Metropolitan Government, english.seoul.go.kr

g. News is reached informatively and updated, not taken from the mass media.

h. The activity documentation is also well documented and provides a comprehensive overview of the program conducted by the Seoul City Government.

Based on the content, the appearance of the city government website in Indonesia has met the minimum content requirements specified by the Government of Indonesia through the Ministry of Communication and Information. In the implementation of e-government, the pattern of interaction already included $G 2 \mathrm{G}$, G2B and G2C, but still minimal in the aspect of diplomacy practice.

The results showed that the implementation of e-government in several cities or regencies in Indonesia is still focused on improving the quality of public services. The orientation of data and information distribution is still focused on the local people/audience. The use of multilingual or foreign language options in accessing information is still very minimal. Various fields that can boost the development of the city, such as investment, trade, and tourism with a focus on overseas audiences, are informed well but the data or information presented is not integrated into one portal. Some cities that are doing sister cities cooperation also do not provide information about their sister city's partner. However, there are several cities that are considered by the author to be doing city diplomacy very well, like Jakarta, Bandung, Yogyakarta, and Surabaya, so that the implementation of egovernment can be synergize with city diplomacy activities that can accelerate the city's economic development.

The Author in this study recommend the City in Indonesia in implementing e-government should provide multiple language options in their website, so the global readers/audience could see any kind of information such as city profile, potential resource, trade, investment, small-medium enterprise, tourism, local culture, public figure, etc.). For the city that already had a sister city partnership, they must provide language options that are related to their sister city's partner. Even though it looks like a technical matter, it is very useful to connect G2G, G2C, and G2B relations among the cities partnership. In implementing egovernment, the city government can develop the strategy while managing e-government can also be used for city diplomacy. Here are some strategy concepts in combining e-government and city diplomacy as seen by G2G, G2B, and G2C patterns. (See Figure 5). 

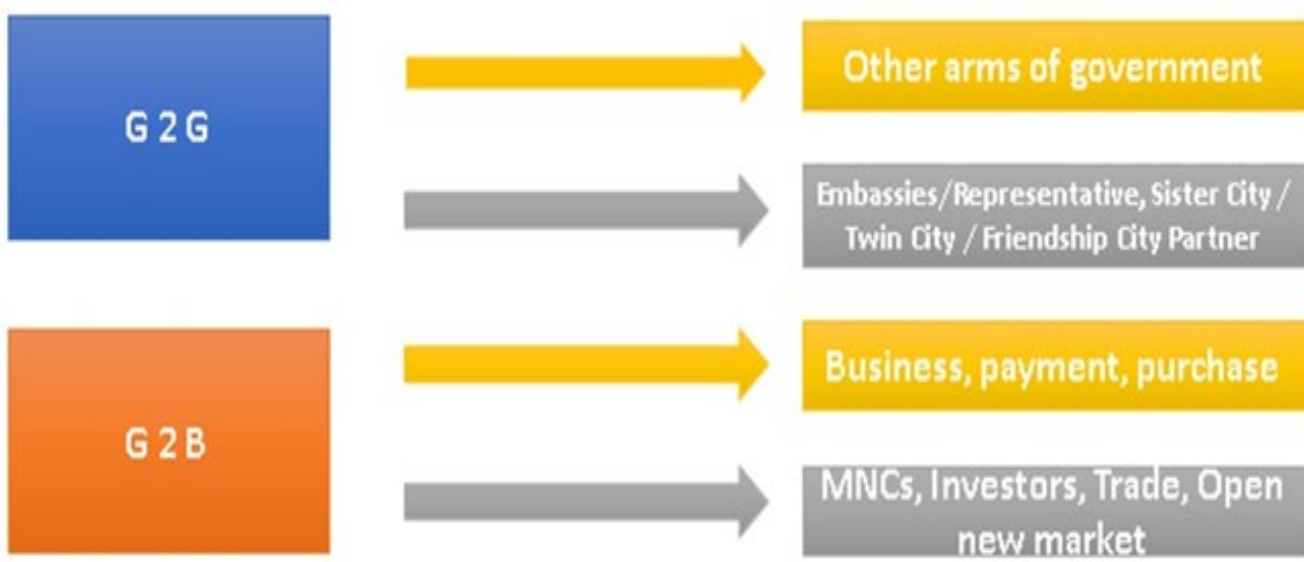

Other arms of government

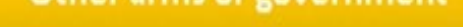

Imbassies/Representative, Sister City /

Twin City / Friendship City Partner

Business, payment, purchase

MNCs, Investors, Trade, Open new market

Local citizens
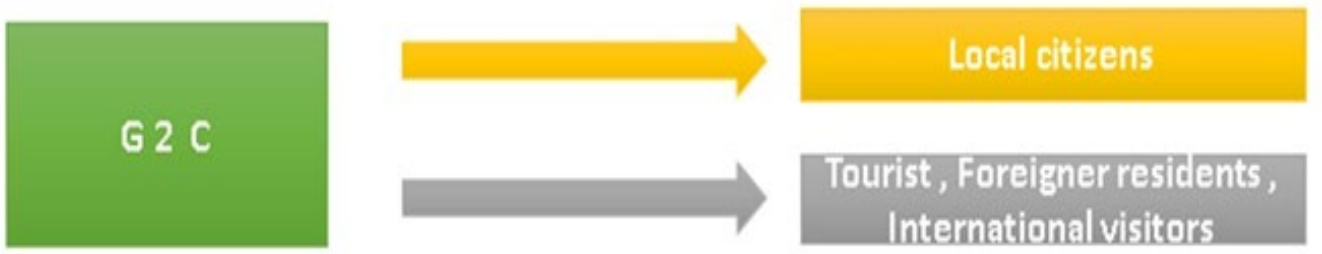

Tourist, Foreigner residents, International visitors

Figure 6: E-Government featuring City Diplomacy's Target Readers

\section{REFERENCES}

Adam Grydehoj. (2014) “Goals, Capabilities, and Instruments of Paradiplomacy". http://www.islanddynamics.org/Grydehoj\%2 0-\%20Paradiplomacy.pdf

Adibowo, R. \& Putri, S.O. (2016). "Penerapan EGovernment Dalam Paradiplomasi Pemerintah Kota Bandung", Jurnal Ilmu Politik dan Komunikasi, Universitas Komputer Indonesia, Vol. 6 No. 2, Desember,2016

Brian Hocking \& Jan Melissen (2015) Diplomacy in the Digital Age, Netherlands Institute of International Relations Clingendael.https://www.clingendael.org/sit es/default/files/pdfs/Digital_Diplomacy_in_t he_Digital\%20Age_Clingendael_July2015.pdf

Criekemans, David (2008) "Are The Boundaries Between Paradiplomacy and Diplomacy Watering Down?", University of Anwerp and Flemish Centre for International Policy, Belgium, in Kurniawan Ariadi Paradiplomasi, Otonomi Daerah dan Hubungan Luar Negeri. http://perpustakaan.bappenas.go.id/lontar/fi le?file=digital/78085-[_Konten_] Artikel\%20A.47-21-00.pdf
Darmayanti, Christy. (2011) Transformasi, Potensi Paradiplomasi Dalam mendukung Kinerja Diplomasi Indonesia Menuju Komunitas ASEAN.Yogyakarta: Universitas Slamet Riyadi

Eugene D. Zapata Garesché, (2007) “Practical Manual for the internationalisation of Cities",

http://observocd.org/sites/observocd.org/fil es/publicacion/docs/314_148.pdf p.18

Hyung Min Lee, Kevin Y. Wang, and Yejin Hong (2013) E-Government in Public Diplomacy: An Exploratory Analysis on Factors Affecting Interactive Interfaces in Ministry of Foreign Affairs Web Sites.

https://www.igiglobal.com/chapter/government-publicdiplomacy/77453\#: :text=In\%20fact $\% 2 C \% 2$ OE-

Government\%20in\%20public\%20diplomacy \%20appears\%20to,consultation\%20overseas \%20\%28Ebbers\%20et\%20al.\%2C\%202008\%3B \%20Khalil\%2C\%202011\%29.

Kuznetsov A.S. (2015): Subnational Governments in International Affairs: A Study on Theory and Practice of Paradiplomacy, New York, Routledge 
Mahnaz Goodarzi \& Mohammad Kaffash Nayyeri (2016) Globalization and City Diplomacy: The Formation of Global Citizen (Possibility or Impossibility). International Journal of Humanities And Cultural Studies ISSN 23565926 Vol 3 Issue 1 June 2016

Magone, J.M, Paradiplomacy Revisited: The Structure of Opportunities of Global Governance and Regional Actors http://paradiplomacia.org/upload/dow nloads/66fc7ecc666b857d415ee890307ab79 cjosemagonefinal.pdf

Marchetti, Raffaele. (2021) City diplomacy"A New Chance For The Italian G20 Presidency, https://sog.luiss.it/sites/sog.luiss.it/files /LUISS_SOG_policybrief\%2015_21_ENG. pdf

Melissen, Jan and Paul Sharp (2006) Editorial The Hague Journal of Diplomacy Vol.1 No.1

Michaelmann, H \& Soldatos, P. (1990). Federalism and International Relations: The Role of Subnational Units. Oxford, Clarendon Press

Official Website of the Bandung City, https://bandung.go.id/

Official Website of the Jakarta City, https://jakarta.go.id

Official Website of the Medan City, https://pemkomedan.go.id

Official Website of the Seoul Metropolitan Government, english.seoul.go.kr

Official Website of Diskominfo Bogor http://kominfo.kotabogor.go.id/index.php/po st/single/27

Pacific Council On International Policy Document (2002) Roadmap for E-government in the Developing World 10 Questions EGovernment Leaders Should Ask Themselves. https://www.itu.int/net/wsis/docs/backgrou nd/themes/egov/pacific_council.pdf

Panduan Pengelolaan Situs Web Pemerintah, http://ppid.probolinggokota.go.id/wpcontent/uploads/2019/11/PanduanPengelolaan-Situs-Web-2019.pdf

Pujayanti, A. (2016) Peran Daerah dalam Diplomasi Ekonomi Jurnal Politica Vol.7 No 1 2016, accessed from https://jurnal.dpr.go.id/index.php/politi ca/article/download/1118/611
Richardus Eko Indrajit. (2004) Electronic Government: Strategi Pembangunan dan Pengembangan Sistem Pelayanan Publik Berbasis Teknologi Digital.

Richardus Eko Indrajit. (2005) E-Government in Action: Ragam Kasus Implementasi Sukses di Berbagai Belahan Dunia

Rogier Van der Pluijm \& Jan Melissen (2007) City Diplomacy: The Expanding Role of Cities in International Politics, Netherland Institue of International Relations Clingendael / Clingendael Diplomacy Papers No.10 The Hague

Sosiawan, E.A “Evaluasi Implementasi EGovernment Pada Situs Web Pemerintah Daerah Di Indonesia: Prespektif Content dan Manajemen" http:/ / kominfo.kotabogor.go.id/asset/ fi le/sop/evaluasi-implementasi-egovpada-web.pdf

UN E-Government Survey 2020 - United Nations.https://publicadministration.un.org /egovkb/en-us/Reports/UN-E-GovernmentSurvey-2020

\section{ABOUT THE AUTHOR}

Sylvia Octa Putri, email: sylvia.octa.putri@email.unikom.ac.id

Sylvia Octa Putri, Department of International Relations, Universitas Komputer Indonesia, West Java, Indonesia 